\title{
PERCEPTION OF FARMERS ON THE CONTRIBUTION OF VEGETABLES TO LIVELIHOODS IN YAKURR LOCAL GOVERNMENT AREA, CROSS RIVER STATE, NIGERIA
}

\author{
EFFIONG, J. B., ABOH, C. L. AND AYA, C. F.
}

(Received 23 April 2021; Revision Accepted 24 May 2021)

\begin{abstract}
This study assessed the perception of farmers on the contribution of vegetables to livelihoods in Yakurr Local Government Area of Cross River State, Nigeria. The study identified the socio-economic characteristics of farmers in the study area, perception of the contribution of vegetables to livelihoods and identified the factors affecting vegetable farming in the study area. Multi-stage sampling techniques were adopted in selecting 126 respondents for the study. Data were collected with the aid of a questionnaire and analyzed using descriptive statistics such as percentage, frequency, mean and ranks. The result of the study showed that majority $(75.4 \%)$ of the respondents were females. Most of the farmers (41.3\%) were aged between 36 and 45 years. Some $(44.4 \%)$ were involved in the cultivation of

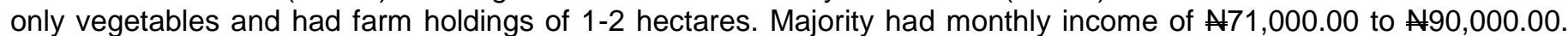
The result of the type of vegetables grown by the respondents revealed that fluted pumpkin ranked $1^{\text {st }}(x=2.68)$ while Utazi ranked $9^{\text {th }}(x=1.93)$. Also the result of the perception of farmers on the contribution of vegetables to livelihoods of farmers showed that vegetables contributed to the income of respondents for training as fashion designers in the study area and were generally excellent. Factors affecting contribution of vegetables to livelihoods were inadequate land, inadequate finance, pests and diseases among others. Vegetables, therefore played a very important role in the livelihoods of farmers in the study area. The study concluded that vegetables are necessary for the improvement of livelihoods of farmers in Yakurr Local Government Area, Cross River State, Nigeria.
\end{abstract}

\section{INTRODUCTION}

There are many kinds of vegetables planted in African soil such as, fluted pumpkin, okra, waterleaf, pepper, bitter leaf, tomato among others. They are main sources of nutrients, vitamins, antioxidants, minerals, proteins among many others. Some vegetables are used for medicinal purposes and are sold locally, thus improving economic status of communities. These vegetables vary according to local and climatic conditions. Luchen and Mingchi (2015) stated that some wild plants are specific to areas and ethnic groups. The indication is that from a variety of wild leafy plants, a certain ethnic group may acknowledge and use only a few plants and regard others as weeds, while others acknowledge such species as major sources of food and nutrition.
Vegetables play important roles in human body especially those concerning essential vitamins and mineral elements, thus, resulting in the prevention of the problem of malnutrition. Effiong, Ijioma and Effiong (2016) and FAO (2010) pointed out that the problem of malnutrition is mostly escalated among children and pregnant women, and is responsible for high mortality rates of these groups. Insufficient consumption of vegetables annually cause about 2.1 million deaths worldwide, and is one of the top ten risk factors contributing to human mortality (Effiong, Effiong and Udo, 2015; Effiong and Aboh, 2019; Aboh and Effiong, 2019 and Prescott-Allen and Prescott-Allen, 2010). This necessitates the inclusion of vegetables (especially where exotic vegetables are not affordable) in diet to alleviate problem of hunger and malnutrition that are

Effiong, J. B., Department of Agricultural Extension and Rural Sociology, Faculty of Agriculture, Forestry and Wildlife Resources Management University of Calabar, Calabar.

Aboh, C. L., Department of Agricultural Extension and Rural Sociology, Faculty of Agriculture, Forestry and Wildlife Resources Management University of Calabar, Calabar.

Aya, C. F., Department of Agricultural Extension and Rural Sociology, Faculty of Agriculture, Forestry and Wildlife Resources Management University of Calabar, Calabar. 
prevalent in Nigeria. Effiong and Asikong (2013) and Laker (2016) indicated that indigenous vegetables such as Moringa, sword bean (lablab spp.), country bean (Dolichos sp.), Luffa, aroids (Colocasia,

Amorphophallus, Alocasia, Xanthosoma), Cucurbits, yam (Dioscorea), leafy vegetables supplemented are sources of foods and employment leading to improved livelihood and poverty alleviation. According to Effiong and Asikong (2003), these all important crops have essentially turned out to be a major source of livelihoods to vast majority of the people of Yakurr Local Government Area in Cross River State, Nigeria.

In Cross River State, vegetable consumption in diets augments nutritive values of staple foods like rice, beans, yam and maize due to their vitamins, minerals, protein, sugar and oils thereby controlling the incidence of hunger (Effiong and Aboh, 2018) and (Aboh and Effiong, 2019). For this reason, the World Health Organization (WHO) recommended daily intake of $400-$ $800 \mathrm{~g} /$ day of vegetables worldwide. However, in Nigeria, the daily intake of vegetable ranges from 200 $450 \mathrm{~g} /$ day. This is because of the current economic recession; consumers are more interested in the quantity of food they consume and not the quality (WHO, 2000), (Effiong, Effiong and Udo, 2015) and (Effiong and Aboh, 2019).

A person's livelihood refers to his/her "means of securing the basic necessities of life - food, water, shelter and clothing (Effiong, 2012). Livelihood is as a set of activities performed to live for a life span, involving securing food, water, medicine, clothing, shelter, and the capacity to acquire wealth by working either individually or as a group using endowments of both human and material resources for meeting the requirements of his/her household on a suitable basis with dignity (Effiong, 2013; FAO, 2000; Aboh and Effiong, 2019). The activities are usually carried out overtime and repeatedly. For instance, a fisherman's livelihood depends on the availability and accessibility of fish (Effiong, 2012) and (Chambers and Conway, 1992). Also, livelihood comprises the capabilities, assets (including both material and social resources) and activities required for a means of living (Effiong and Aboh, 2018). Livelihood is sustainable when it can cope with and recover from stress and shocks and maintain or enhance its capabilities and assets both now and in the future while not undermining the natural resource base of the beneficiary (WHO, 2000; Scoones, 2018; Effiong and Aboh, 2019). Despite the perceived usefulness and untapped potential of vegetables, it has been neglected by farmers and rural dwellers. This may lead to negative effect on food security, socio-economic conditions and livelihood activities of rural people in Yakurr Local Government Area of Cross River State, Nigeria.

\section{METHODOLOGY}

This study was carried out in Yakurr Local Government Area of Cross River State. Yakurr was created from Obubra Local Government Area in 1987. It is located in longitude $5^{\circ} 79^{\prime} 73^{\circ} \mathrm{N}$ and latitude $8^{\circ} 17^{\prime} 76 \mathrm{E}$ of the equator. It has a large landmass with an area of 670 $\mathrm{km}^{2}$. It has its boundary with Abi to the East, Obubra to the North, Biase to the East, and Akamkpa Local Government Area to the West. It comprise of 13 Wards and is inhabited by the people of Agoi Ibmai, Assiga, Mkpani, Ekori, Nko, Ugep and Idomi. The dominant language is Yakurr. The people of the area are largely farmers (Effiong and Asikong, 2013). The area produces Yam, Cocoyam, Cassava, Plantain, Beans, Maize and Pumpkin. Cash crops include: oil palm, cocoa, cashew, and rubber. The area is near the rainforest belts and so the vegetation is that of tropical rainforest. The area consists of small and medium scale farmers who predominantly cultivate cassava and yam. The intercrops are fluted pumpkin, melon, sweet yam, cocoa yam, and water yam. Apart from farming, they are also engaged in palm wine tapping, welding works, processing of wild palm fruits, tailoring, trading and processing of cassava into garri for sale and consumption (Effiong and Asikong, 2013; Effiong, ljioma and Effiong, 2016).

Descriptive survey was adopted for this study. This design was considered appropriate since the study intended to use the information obtained through questionnaires in describing observed phenomena. Thus the information provided by vegetable farmers were used to describe the observations, deductions made and conclusions drawn.

The population of the study comprised all registered vegetable (fluted pumpkin, waterleaf, okra, lettuce (afang), bitter leaf, scent leaf) farmers in Yakurr Local Government Area of Cross River State., Nigeria.

A multi-stage random sampling technique was adopted in selecting respondents for the study. The first stage was a simple random selection of 9 (representing $80 \%$ ) cells (units) out of the 13 cells (units) in Yakurr block. At the second stage, a random sampling of fourteen (14) vegetable farmers from each of the 9 cells were conducted in the study area. This gave a total of 126 respondents used for the study. 
RESULTS AND DISCUSSION

Table 1: Distribution of respondents according to socio-economic characteristics

\begin{tabular}{ll}
\hline & Fender \\
Male & \\
Female & \\
Total & \\
Age &
\end{tabular}

Frequency

31

95

126

6

46

52

22

126

Total

Marital Status

Single

Married

Total

Farm Size

$1-2$

$3-4$

$5-6$

Total

Household Size

$1-2$

$3-4$

$5-6$

Total

Social Organization

Men/Women Religious Society

Young Farmers' Club

Agricultural Cooperative Society

Age-grade Society

Total

100

66.7

31.0

2.4

100

84

39

3

126

66.7

31.0

2.4

100

55

25

17

29

126

43.7

19.8

13.5

23.0

100

Systems of Land Ownership

Inheritance

Leasehold

29

12

Purchase

Communal/free gift

Total

Education level

No formal education

Primary level

Secondary level

25.4

Tertiary level

Total

Major occupation

Farming

Civil servant

Trading

Total 
EFFIONG, J. B., ABOH, C. L. AND AYA, C. F.

Type of farming

Only vegetables

Vegetables and livelihood

Vegetables and aquaculture

Vegetable and other crops

Total
56

15

24

31

126
44.4

11.9

19.0

24.6

100

Monthly income

$<71,000$

39

31.0

$<1,000-90,000$

$91,000-110,000$

45

35.7

30

23.8

$111,000-130,000$

10

$>130,000$

2

126

7.9

1.6

100

Farming Experience

Below 1.5

$38 \quad 30.2$

$6-10$

$11-15$

$16-20$

Above 20

70

55.6

$12 \quad 9.5$

$4 \quad 32$

Total

1.6

126

100

\section{Source: Field Survey, 2019}

\section{SOCIO-ECONOMIC CHARACTERISTICS OF THE RESPONDENTS}

The results in Table 1 shows the distribution of respondents according to socio-economic characteristics. The results indicate that majority $(75.4 \%$ of the vegetables farmers were females. The age bracket of majority $(41.3 \%)$ of the farmers was $36-45$ years with a large majority $(74.6 \%)$ being married. About $45.2 \%$ had farming as their major occupation; $44.4 \%$ were involved in the cultivation of vegetables, having farm sizes ranging from $1-2$ hectares as indicated by a high majority of $66.7 \%$ of the farmers; also, a majority (55.6\%) owned land by inheritance. About $28.4 \%$ of the farmers had primary level of education, also $35.7 \%$ had

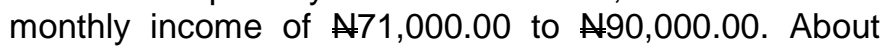
majority $55.6 \%$ had $6-10$ years of farming experience in the study area.

This result corroborates that of Effiong, ljeoma and Effiong (2016) whose result revealed that vegetable farmers were predominantly females $(78 \%) ; 6 \%$ of males cultivated the crop for commercial purposes while $16 \%$ of males supported their wives to cultivate for subsistence purposes. A study by Ayanwuyi, Ogunlade, and Oyetoro (2010) revealed that about $72.0 \%$ of vegetable farmers in Oyo State, Nigeria were females and $95.8 \%$ were between 31 and 51 years old. While $29.4 \%$ had no formal education, $70.6 \%$ had various levels of education. About $90 \%$ of the farmers had many years of farming experience ranging from 6 years to 21 years and above. The result of this study is also in line with a study by Effiong, Effiong and Udo (2015) who revealed that 66.7 percent of the respondents were aged between $31-50$ years; 72.2 percent were married and 53.3 percent had farming experience of about 9 years. Also, the result is in contrast with the study by Oluwa and Oluwa (2016) which revealed that about 7\% of vegetable farmers are land owners, $3 \%$ inherited land while $90 \%$ obtained their farmland on lease basis in Lagos State, Nigeria.

Table 2: Distribution of respondents according to type of vegetables grown

\begin{tabular}{lllllll}
\hline Vegetables & $\begin{array}{l}\text { Always } \\
\text { cultivated }\end{array}$ & $\begin{array}{l}\text { Sometimes } \\
\text { cultivated }\end{array}$ & $\begin{array}{l}\text { Never } \\
\text { cultivated }\end{array}$ & Mean & Rank \\
\hline 1 & Fluted pumpkin & $94(282)$ & $26(52)$ & 6 & $2.68^{*}$ & 1 \\
2 & Okra & $68(204)$ & $48(96)$ & 10 & $2.46^{*}$ & 2 \\
3 & Water leaf & $51(153)$ & $73(146)$ & 2 & $2.39^{*}$ & 3 \\
4 & Pepper & $63(189)$ & $50(100)$ & 13 & $2.39^{*}$ & 4 \\
5 & Tomato & $36(108)$ & $70(140)$ & 20 & $2.13^{*}$ & 5 \\
6 & Bitter leaf & $41(123)$ & $52(104)$ & 33 & $2.06^{*}$ & 6 \\
7 & Spinach (green leaf) & $34(102)$ & $62(124)$ & 30 & $2.03^{*}$ & 7 \\
8 & Lettuce (afang/atama) & $40(120)$ & $45(90)$ & 41 & 1.99 & 8 \\
9 & Utazi & $43(111)$ & $43(86)$ & 46 & 1.93 & 9 \\
\hline
\end{tabular}


The result in Table 2 showed the distribution of respondents according to the type of vegetables grown in the study area. From the result, Fluted pumpkin ranked $1^{\text {st }}(x=2.68)$, Okra ranked $2^{\text {nd }}(x=2.46)$, Water leaf ranked $3^{\text {rd }}(x=2.39)$, Pepper ranked $4^{\text {th }}(x-2.39)$, Tomato ranked $5^{\text {th }}(x=2.13)$, Bitter leaf ranked $6^{\text {th }}(x=2.06)$, while Spinach $7^{\text {th }} \quad(x=2.03)$ and were the major type of vegetables grown in the study area. According to Effiong (2013) vegetables grown by farmers in Nigeria include: Pumpkin, Water leaf, Bitter leaf, Scent leaf, Garden egg,
Green, Okro, Tomato, and Afang leaf. According to Effiong and Aboh (2018), some of the farmers grew traditional vegetables such as spider plant, Amarantus species and pumpkin leaves. Findings by Effiong (2013), Aboh and Effiong (2019) indicate that vegetable production in Nigeria has been on the increase for leafy vegetables like Amaranthus, Water leaf, Bitter Leaf, Lettuce, Telfaira as well as non-leafy vegetables like tomato, watermelon, and

Table 3: Distribution of respondents according to perception on the contribution of vegetables to livelihoods

\begin{tabular}{|c|c|c|c|c|c|c|c|c|}
\hline & Variables & Excellent & $\begin{array}{l}\text { Very } \\
\text { good }\end{array}$ & Good & Fair & $\begin{array}{l}\text { Not } \\
\text { fair }\end{array}$ & mean & rank \\
\hline 1 & Fashion Design & $100(50)$ & $22(88)$ & $3(9)$ & 1 & - & $4.75^{\star}$ & 1 \\
\hline 2 & Shoe making & $32(160)$ & $65(260)$ & $22(66)$ & $3(6)$ & 4 & $4.65^{\star}$ & 2 \\
\hline 3 & Nutrition advancement & $88(440)$ & $29(116)$ & $6(18)$ & $3(6)$ & - & $4.60^{*}$ & 3 \\
\hline 4 & Education of children & $38(190)$ & $64(256)$ & $18(54)$ & $5(10)$ & 1 & $4.06^{*}$ & 3 \\
\hline 5 & Farm financing & $47(235)$ & $39(156)$ & $23(69)$ & $10(20)$ & 7 & $3.87^{*}$ & 5 \\
\hline 6 & Livestock keeping & $29(145)$ & $52(208)$ & $24(72)$ & $13(26)$ & 8 & $3.64^{*}$ & 6 \\
\hline 7 & Health Education of farmers & $28(140)$ & $41(164)$ & $39(117)$ & $10(20)$ & 8 & $3.56^{\star}$ & 7 \\
\hline 8 & Processing of farm products & $33(165)$ & $39(156)$ & $29(87)$ & $13(26)$ & 12 & 3.54 & 8 \\
\hline 9 & Transportation systems & $37(185)$ & $27(108)$ & $40(120)$ & $8(16)$ & 14 & $3.52^{*}$ & 9 \\
\hline 10 & Storage services & $30(150)$ & $42(168)$ & $31(93)$ & $10(20)$ & 13 & $3.52^{*}$ & 10 \\
\hline 11 & Assets renting & $34(170)$ & $38(152)$ & $28(84)$ & $12(24)$ & 14 & $3.52^{*}$ & 11 \\
\hline 12 & Financial management & $32(160)$ & $36(144)$ & $31(93)$ & $13(26)$ & 14 & $3.47^{\star}$ & 12 \\
\hline 13 & Food vendor & $26(130)$ & $37(148)$ & $40(120)$ & $15(30)$ & 8 & $3.46^{*}$ & 13 \\
\hline 14 & Crop productivity & $32(160)$ & $35(140)$ & $26(78)$ & $17(34)$ & 16 & $3.39^{*}$ & 14 \\
\hline 15 & Membership of farming groups & $28(140)$ & $33(132)$ & $37(111)$ & $15(30)$ & 13 & $3.38^{*}$ & 15 \\
\hline 16 & Community security service & $29(145)$ & $33(132)$ & $35(105)$ & $10(20)$ & 19 & $3.34^{*}$ & 16 \\
\hline 17 & Farm input supplier & $24(120)$ & $43(172)$ & $30(90)$ & $11(22)$ & 18 & $3.35^{\star}$ & 17 \\
\hline
\end{tabular}

Source: Field Survey, 2019

\section{CONTRIBUTION OF VEGETABLES TO LIVELIHOODS}

The result in Table 3 showed the distribution of respondents' perception on contribution of vegetable to livelihoods. The result revealed that vegetables contributed to income of farmers used in having training as fashion designers and ranked $1^{\text {st }}(x=4.75)$, shoe making ranked $2^{\text {nd }}(x=465)$, nutrition advancement ranked $3^{\text {rd }}(x=4.60)$, education of children ranked $4^{\text {th }}$ $(x=4.06)$ among othefs and were generally excellent. Ngegba, Sesay and Bangura (2016) carried out a study and found that the livelihood status of vegetable farmers in terms of community security services (48.4\%) was excellent, while crop productivity had (73.3\%) and communication systems (63.3\%), drinking water supply
(36.1\%) and were very good. This study is in agreement with Effiong, ljeoma and Effiong (2016) who asserted that vegetable production is a sin-qua-non to livelihoods. Access to farm inputs supply (44.4\%), processing of farm products $(43.3 \%)$, and food vendor (48.3\%) were expressed as being good in the study. This finding is in accordance with what Ayodele (2005) observed in his study that food product processing is a livelihood activity derived from arable crop production. Also, the shoe making $(80.0 \%)$, livestock keeping $(77.8 \%)$, children's education status $(70.0 \%)$, financial management activities $(66.7 \%)$, health education of the farmers (55.5\%), assets renting was $54.4 \%$ and were ascribed fair statuses. 
Table 4: Distribution of respondents based on their perception of factors affecting vegetable production in the study area

\begin{tabular}{|c|c|c|c|c|c|c|c|c|}
\hline $\mathbf{S} / \mathbf{N}$ & Variables & SA & A & $\mathbf{U}$ & D & SD & Mean & Rank \\
\hline 1 & Inadequate land & $87(435)$ & $24(96)$ & $5(15)$ & $8(16)$ & 2 & $4.48^{\star}$ & 1 \\
\hline 2 & Inadequate finances & $25(125)$ & $67(268)$ & $21(63)$ & $5(10)$ & 8 & $3.76^{\star}$ & 2 \\
\hline 3 & $\begin{array}{ll}\text { Chicken } & \text { destroying } \\
\text { vegetable } & \end{array}$ & $45(225)$ & $29(116)$ & $25(75)$ & $18(36)$ & 9 & $3.66^{*}$ & 3 \\
\hline 4 & Vegetable theft & $40(200)$ & $40(160)$ & $21(63)$ & $13(26)$ & 12 & $3.66^{*}$ & 3 \\
\hline 5 & Heavy rainfall & $29(145)$ & $54(216)$ & $20(60)$ & $15(30)$ & 8 & $3.64^{*}$ & 5 \\
\hline 6 & $\begin{array}{l}\text { Insufficient market for } \\
\text { selling vegetables }\end{array}$ & $40(200)$ & $39(156)$ & 23(69) & $14(28)$ & 10 & $3.63^{*}$ & 6 \\
\hline 7 & Insufficient water & $29(145)$ & 41(164) & $34(102)$ & $11(22)$ & 11 & $3.52^{*}$ & 7 \\
\hline 8 & Restrictive village policy & $28(140)$ & $43(172)$ & $28(84)$ & $15(30)$ & 12 & $3.48^{*}$ & 8 \\
\hline 9 & Pests and diseases & $23(115)$ & $54(216)$ & $16(48)$ & $21(42)$ & 12 & $3.44^{*}$ & 9 \\
\hline 10 & Poor transportation & $23(115)$ & $52(208)$ & $22(66)$ & $15(30)$ & 14 & $3.44^{*}$ & 9 \\
\hline
\end{tabular}

Source: Field survey, 2019

\section{FACTORS AFFECTING THE CONTRIBUTION OF VEGETABLES TO LIVELIHOOD}

The result in Table 4 shows the distribution of respondents base on factors affecting contribution of vegetables to livelithoods in the study area. The study revealed that inadequate land $(x=4.48)$, inadequate finance $(x=3.76)$, chicken destroying crops $(x=3.66)$, among others were the major factors affecting the cultivation of vegetables in the study area. Others were pests, diseases and insufficient rainfall, while marketing constraints were; poor crop prices, exploitation by middlemen, post-harvest losses, inadequate market information, low consumer awareness and low demand. According to Effiong and Udo (2015), major constraints to production of vegetables includes; pests and disease infestation, inadequate extension services, high cost of labour and inadequate access to credit facilities. Low vegetable production was attributed to pests, diseases, seeds, land unavailability, inappropriate husbandry practices and lack of awareness on the crop's nutritional value.

\section{SUMMARY}

This study concludes that vegetables play important role in the livelihood of rural farmers. This is evidenced in its contribution to income, housing conditions, nutrition, education of children and general livelihood variables as perceived by farmers. Though other vegetables are produced, farmers mostly cultivated fluted pumpkin in large quantities; this is attributable to its high market demand in the study area. For increased and continued production of vegetables in Yakurr, an enabling environment should be created for the farmers who are the rural disadvantaged but produces the bulk of the vegetables consumed in the country.

Thus vegetable production in the study area is gender friendly though women driven and a serious business because it provides means of livelihoods for most Cross Riverians, Nigerians and their families. It plays an important role in the improvement of the health of citizens, safeguards environments and provides raw materials and food.

\section{REFERENCES}

Aboh, C. L. and Effiong, J. B., 2019. Assessment of indigenous weed management techniques utilized by cocoa farmers in Akamkpa, Cross River State, Nigeria. European Journal of Scientific Research, Vol.154 (1): 134-141.

Aboh, C. L. and Effiong, J. B., 2019. Indigenous marine resources management techniques among fisher folks in Calabar South Local Government Area, Nigeria. Kasmera Journal, Vol.47(2).

Ayanwuyi, E. K., F., Ogunlade, A. I. and Oyetoro, J. O., 2010. Farmers' perception of impact of climate change on food crop production In Ogbomoso Agricultural Zone of Oyo State, Nigeria. Continental Journal of Agricultural Economics, 4(1):24-33.

Ayodele, A. E., 2005. The medicinally important leafy vegetables of south western Nigeria. Available from: http://.www.siu.edu/-ebl/leaflets/ayode le.htm.

Chambers, R. and Conway, G. R., 1992. Sustainable Rural Livelihoods: Practical Concepts for the $21^{\text {st }}$ Century. IDS Discussion Paper, issue 296.

Effiong, J. B. and Aboh, C. L., 2014. Utilization of ICT tools among final year students of agricultural medical sciences, University of Calabar, Nigeria. Kasmera Journal, Vol. 47(2).

Effiong, J. B. and Aboh, C. L., 2018. Rubber production Technologies and the related socio-economic environment in Akwa lbom State, Nigeria. Global Journal of Agricultural Science, 17(1):1522, 2018.

Effiong, J. B. and Aboh, C. L., 2019. Effect of agrochemical on the health of farmers in Akpabuyo Local Government Area, Cross River State, Nigeria. European Journal of Scientific Research, Vol. 154(1): 142-147. 
Effiong, J. B. and Asikong, A. B., 2013. Mid-term Assessment of the activities of Fadama 111 development project in Cross River State. Global Journal of Agricultural science, 12(1): 3135, 2013.

Effiong, J. B., 2012. An Analysis of Agricultural livelihood activities prevalent among Rural farmers in Itu L.G.A, Akwa lbom State. African Journal of Agricultural Research and Development, 5(3), 31-45, 2012.

Effiong, J. B., 2013. Challenges and prospect of Rural Women in Agricultural production in Nigeria. Lwati: A journal of Contemporary Resources, 10(2): 183-190, 2013.

Effiong, J. B., 2013. Prospects and constraints of indigenous agricultural practices among rural farmers in Itu L.G.A, Akwa Ibom State, Nigeria. Agricultural Journal, 81: 22-25, 2013.

Effiong, J. B., Effiong, G. B. and Udo, U. A., 2015. Socio-economic determination of production of pro-vitamin: A cassava varieties by farmers in Etim Ekpo Local government Area, Akwa Ibom State, Nigeria. Global Journal of Agriculture Science, 21(2): 105-111, 2015.

Effiong, J. B., ijioma, J. C. and Effiong M. O., 2016. Endogenous determinants of adoption of improved rubber production Technologies among farmers in Akwa lbom State. Nigeria. Asian Journal of Agricultural Extension ,Economic \& Sociology, 8(4): 1-8, 2016.

F.A.O (Food and Agricultural Organization) 2006. World Food Security: A Reappraisal of the concepts and Approaches. Director General Reports. Rome Italy, 3-10.

Laker, M. C., 2016. Indigenous crops, water and human nutrition. International Symposium on the nutritional value and water use for indigenous crops for improved livelihoods. Water SA, 33(3): 15-20.

Luchen, S. W. S., and Mingochi, D. S., 2015. Traditional vegetables in Zambia: genetic resources, cultivation and uses. Proceedings of the IPGRI International Workshop on Genetics.

Ngegbe, M. P., Sesay, M. and Banguru, E. T., 2016. The impact of vegetable farming on the livelihood of small-scale farmers in Koinadugu District Northern Sierra Leone. Global Journal of Bio-Science and Bio-Technology, 5(1):42-49.

Olowa, O. W., and Olowa, O. A., 2016. Assessment of Economic viability of fluted pumpkin farming in Ikorodu LGA, Lagos State. World Rural Observations, 8(1)5-8. Retrieved from http://www.science pub.net/rural.

Prescott-Allen, R. and Prescott-Allen, C., 2010. How many plants fed the world. Conservation Biology, (4):365.

Scoones, I., 2018. Sustainable rural livelihoods: a framework for analysis; working paper 72, Institute of development studies, University of Sussex, Sussex.

Von Braun, J., Swaminathan, M. S. and Rosegrant, M. W., 2014. Agriculture, food, security, nutrition conservation. Biology (4): 365. World Health Organization Report-WHO 2000. Geneva, Switzerland, $17-20$ 